\title{
Immunological aspects of liver disease
}

\author{
A L W F Eddleston, P T Donaldson, J E Hegarty, B D Reed
}

\section{The early years}

The immunology section of the Liver Unit began, like so many other research areas in those early days, as a foray into the unknown by enthusiastic but relatively inexperienced research fellows. During an eventful year as a medical registrar at Dulwich Hospital in 1967, Adrian Eddleston was enlisted as both injector of Technetium sulphur colloid in the Physics Department at King's and interpreter of the resulting liver scintiscans, and soon found that his appetite for research first kindled in Oxford, was alive and well. Hot spleens and cold livers, the norm in cirrhosis, were tracked down to changes in blood flow in the two organs, after some stimulating discussions with Laurie Blendis, an uncompromising but wonderfully stimulating research mentor.

Adrian joined the research staff of the Liver Unit in the next year, and expressed an interest in studying the immunology of autoimmune liver diseases, an area of almost complete ignorance both generally and at a personal level! The power of effector lymphocytes as opposed to the more popular antibodies was just beginning to be perceived, and as the first step in a steep learning curve, Adrian went to Copenhagen to learn the new technique of leucocyte migration inhibition from its inventors, Søborg and Bendixen, who were interested in the cellular immune basis of organ specific autoimmunity. ${ }^{2}$

Autoimmune chronic active hepatitis seemed a promising candidate for an organ specific autoimmune liver disease, and with a crude liver homogenate as an antigenic stimulus in the leucocyte migration inhibition test, Adrian Eddleston began to probe for liver directed cellular autoimmunity. The King's/Cambridge liver transplant programme was just beginning at that time, and there was curiosity as to what the leucocyte migration inhibition test would do in transplant rejection. The results in the first case followed serially, with migration indices measured every other day, were interesting enough to appear in a letter to Nature ${ }^{3}$ ! Rejection began on the seventh day, as judged by the upturn in the serum aspartate aminotransferase. Up to that point all migration indices had been normal. On the morning of the eighth day, inspection of the migrations showed that ... the incubator thermostat had stuck and roasted all the samples set up the day before! Sample taken on the ninth and 13th days, however, showed profound leucocyte migration inhibition in the presence of liver homogenate, which promptly disappeared in subsequent samples taken after a burst of increased immnosuppression. This work led to a Wellcome Trust grant to study cellular immune responses to liver, kidney and human leucocyte antigens in the rejection of liver and kidney grafts.
AUTOIMMUNITY IN LIVER DISEASE

Parallel studies in chronic active hepatitis continued with Martin Smith joining Adrian in 1969, and providing important critical and enthusiastic support. In 1970, to add basic science depth to the research, Adrian, with the help of an MRC Travelling Fellowship, went to work with Bob Good in Minneapolis, USA, as an immunology research fellow, and was exposed for a year and a half to this charismatic figure and his unit. All who have undergone this experience have been profoundly affected by it, and it served to supercharge Adrian's enthusiasm, a dangerous escalation of an already strong trait!

Deborah Doniach, one of the grandparents of clinical immunology, was an important influence at this time. It was she who first introduced us to the work of Meyer zum Buschenfelde on liver specific antigens and experimental autoimmune hepatitis, ${ }^{4}$ and thereby stimulated a series of studies on cellular and humoral immunity to 'LSP', 5 which we now know to be a mixture of lipoproteins derived from the hepatocyte plasma membrane. Initially the complex nature of this 'antigen' was not fully appreciated and we needed the help of a protein biochemist, Ian $\mathrm{McFarlane}$, to standardise its preparation and highlight its complexity, ${ }^{6}$ a task which has occupied him and his research fellow Barbara Wojicka to this day. In fact, Barbara became such an integral part of Ian's life that he married her. It is a testament to their devotion to each other (in addition to LSP) that they are still very happy with each others' company 24 hours a day!

A series of research fellows, many from abroad, have pursued studies on liver specific cellular and humoral autoimmunity over the last 20 years, and it is impossible to pay tribute to all. Some of the notable firsts for the immunology section of the Unit in this area included the finding by Malcolm Cochrane and Alan Thomson of lymphocyte cytotoxicity to rabbit hepatocytes in a microcytotoxicity assay system, ${ }^{7}$ and the later demonstration that this was the result of antibody dependent cytotoxicity ${ }^{8}$; the publication by Adrian Eddleston and Roger Williams of a hypothesis which used the concepts of T-cell mediated help and suppression, to explain how viral induced liver specific autoimmunity could be responsible for the immunopathogenesis of chronic active hepatitis, and how HLA B8 might be tied to this process'; the setting up, by Ian McFarlane and Don Jensen, of a radioimmunoassay for anti-LSP antibodies, ${ }^{10}$ and the discovery by Ian that the asialoglycoprotein receptor known to be a normal component of the hepatocyte surface was present in LSP" and was a major target of liver specific autoantibodies. ${ }^{12}$

Present work in this area includes a study by Ian and Barbara MacFarlane of the epitopes on 
Figure 1: Non-antigenspecific (concanavalin A stimulated) suppressor $T$ cell activity, inhibiting $B$ cell immunoglobulin production, in the peripheral blood lymphocytes (PBL's) of patients with active, untreated autoimmune chronic active hepatitis. The left column illustrates the results obtained with untreated cells whilst the right column shows the return towards normal suppressor cell function after the peripheral blood lymphocytes had been incubated with $5 \times$ $10^{-8} \mathrm{M}$ prednisolone for one hour.
Effect of prednisolone on suppressor cell function

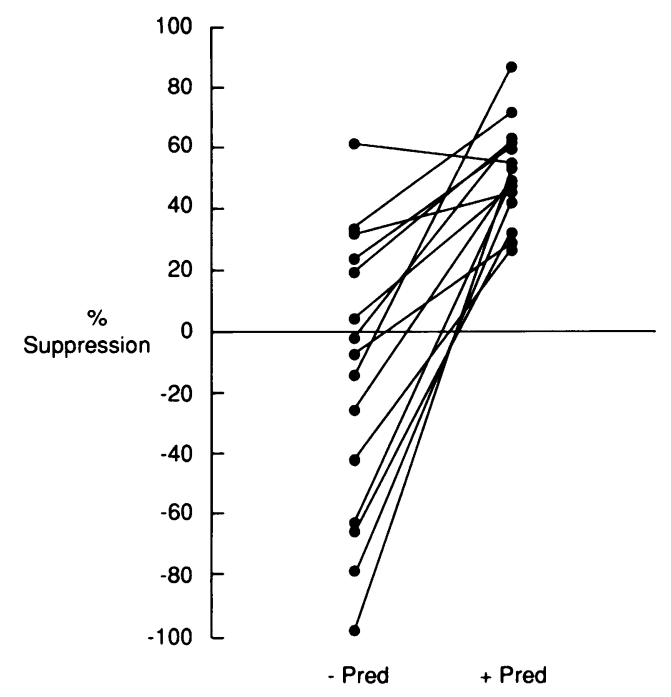

the asialoglycoprotein receptor which are recognised by patient's antibodies; cloning of T cells recognising hepatocyte membrane antigens, including the asialoglycoprotein receptor, from the blood and liver of patients with chronic active hepatitis by Li Wen, who is working with Diego Vergani and Giorgina Mieli-Vergani in the Departments of Immunology and Child Health, and by Xi-Ce Teng in the Liver Unit. The most significant recent development has been the finding by $\mathrm{Li}$ Wen that HLA restricted helper $\mathrm{T}$ cell clones recognising the asialoglycoprotein receptor can cooperate with $B$ cells from the same patient in vitro to produce auto-antibodies reacting with this liver membrane antigen. ${ }^{13}$ This coupled with work on the HLA class II molecules presenting asialoglycoprotein receptor peptides (described later), begins to define all the elements needed to understand the molecular immunology of the disease and provides the tools with which exciting developments in immunotherapy may be designed in the near future.

Returning to the early studies, primary biliary cirrhosis was the other likely organ specific autoimmune disease, with antigens on bile duct epithelium being the obvious targets for immune-mediated damage. The difficulty in obtaining isolated bile duct epithelial cells in man was a major problem when attempting to study antigen-specific cellular immune responses, but the demonstration by Adrian Eddleston that bile antigens to which $T$ cells from patients with primary biliary cirrhosis were sensitised could be found in human bile, ${ }^{14}$ and the demonstration by Ian and Barbara McFarlane that the responsible antigenic components could be partially separated and purified from bile, provided the first evidence of a possible cellular immune basis to primary biliary cirrhosis and primary sclerosing cholangitis. ${ }^{15}$ Difficulties in purifying the bile antigens to homogeneity prevented further progress, but in these days of cDNA libraries and cell lines it is likely that this line of research will again become productive.

Control of humoral and cellular immunity and the mystery of tolerance were clearly of consider- able potential importance in autoimmunity, and major studies pointing to fundamental defects in immunoregulation were completed by Kayhan Nouri-Aria, Sandro Vento, and Charlie O'Brien. Perhaps Kayan's most original contribution was to describe a steroid correctable defect in nonantigen-specific suppression in autoimmune chronic active hepatitis (Fig 1) which was not present in virus induced, hepatitis $B$ positive cases. ${ }^{16}$ Vento and O'Brien concentrated on antigen specific $\mathrm{T}$-cell mediated suppression, ${ }^{17} \mathrm{a}$ fiercely controversial area of research, and one suspects that their original, and fascinating observations identifying a familial defect in antigen-specific suppressor inducer T-cells (Fig $2),{ }^{18} 19$ have yet to be fully appreciated.

\section{IMMUNOPATHOGENESIS OF HEPATITIS B VIRUS} INFECTION

In the early 70s, the discovery of the 'Australia antigen' now known to be the hepatitis B surface antigen, was a powerful stimulus to the immunology section of the unit. Attention turned to hepatitis B virus infection as a model of immunopathogenesis when it became clear to us and others that the virus was not directly cytopathic to liver cells, and that the wide range of clinical presentations of hepatitis B virusinduced liver diseases was almost certainly caused by differences in the immune response to hepatitis $B$ virus antigens. ${ }^{20}$

Two factors were instrumental in ensuring early success for the Liver Unit in this area of research. The first was a very fruitful collaboration, as outlined in a later article, with Professor Arie Zuckerman, whose virological expertise and provision of reliable, sensitive assays for the presence of viral antigens and antibodies in serum, was essential to reliable detection of hepatitis $B$ virus infection. The second factor was the arrival of a young Australian research fellow, Bill Reed. A comprehensive survey of hepatitis B virus in hepatocellular carcinoma in Great Britain was one of the first fruits of Bill Reed's endeavours. ${ }^{21} \mathrm{~A}$ novel attempt to cure chronic hepatitis B virus infection with infusions of anti-HBs antibody was unsuccessful ${ }^{22}$ but Reed made a major contribution to many clinical and laboratory projects including a study of leucocyte migration inhibition with hepatitis B surface antigen as antigen..$^{23}$ After his return to Perth he has continued active research in autoimmune chronic liver disease, further defining target antigens on the hepatocyte membrane ${ }^{24}$ and the control of autoimmune responses to LSP in mice.

Antibodies are easier to work with than sensitised $\mathrm{T}$ cells, and a number of publications from the Unit in the mid 70s looked at the serology of hepatitis B virus infection. Perhaps the most innovative came from the first of a series of excellent Italian research fellows, Alfredo Alberti. When he first arrived, Adrian Eddleston and he discussed the very early clearance of hepatitis $B$ virus virions (Dane particles) in acute hepatitis B, and the rather slow clearance of hepatitis B surface antigen. They decided that logically this could be due to the action of an as yet undefined antibody reacting with an antigen 

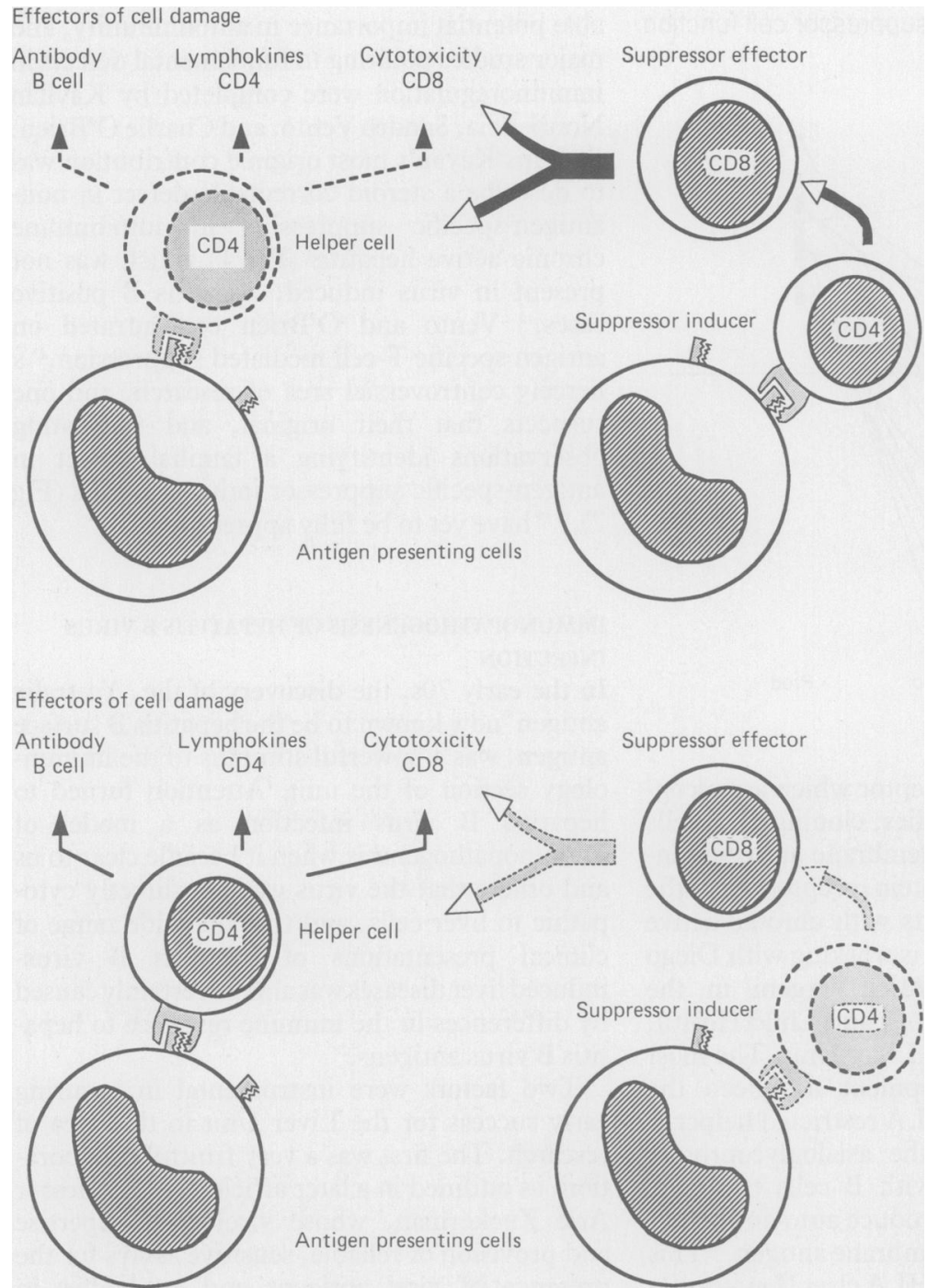

Figure 2: An illustration of the hypothesis that $T$ cell inducers of suppression $(C D 4+v e)$ reacting specifically with the liver membrane antigen, the asialoglycoprotein receptor, are present in normal individuals (above), and prevent the production of effectors of cell damage. The suppressor inducer $T$ cells are absent or ineffective in patients with autoimmune chronic active hepatitis (below), and this allows damaging autoreactivity to develop.

found only on virions. Adrian Eddleston suggested looking for the antibody by immune electron microscopy using acute phase sera mixed with Dane particles. A few weeks later, Alberti, commenting on the early results, said that the antibody might well exist, but the assay was far too insensitive and subjective! He suggested a simple but elegant solution; use the virions own DNA polymerase to specifically label the Dane particles and then use these as antigen in a radioimmuno-precipitation assay. This worked very well, and showed that an antivirion antibody did develop very early in acute hepatitis $B$ virus infection, but was almost always absent in chronic carriers (Fig 3). ${ }^{25} \mathrm{We}$ now know that this was the first detection of a conformational determinant in the pre-S antigen/antibody system expressed on hepatitis $B$ virons, and Alberti has most successfully continued to probe this area of interest after his return to Padua. ${ }^{26}$

The difficulty in studying cell mediated immunopathogenesis of hepatitis B virus infection in man was that there was no infected cell line which could be used as target cells for studying the cytotoxicity of patients' $T$ cells in vitro. Yet again a new Italian research fellow provided the breakthrough needed. Giorgina Mieli-Vergani, who had come to the unit with her husband Diego Vergani in 1976, suggested preparing hepatocytes by collagenase digestion from a small fragment of the patient's diagnostic or follow up liver biopsy, and using these as targets for the patient's own $\mathrm{T}$ cells in a microcytotoxicity assay. Undaunted by most people's scepticism, she proceeded to show the feasibility of this technique in autoimmune chronic active hepatitis, ${ }^{27}$ and using this autologous, thus histocompatability locus matched system, went on to show that $T$ lymphocytes from patients with chronic hepatitis B virus infection were indeed cytotoxic to hepatocytes from the same individual. ${ }^{28}$ The specificity of this $\mathrm{T}$ cell attack was explored by Mario Mondelli, who showed that polyclonal, and monoclonal antibodies reacting with hepatitis B virus core antigen were able to block the $\mathrm{T}$ cell cytotoxicity, while anti-HBe and anti-HBs antibodies did not (Fig 4). ${ }^{29}$ Confirmatory evidence that nucleocapsid components were likely to be an important target antigen for cytolytic $\mathrm{T}$ cells came from Nicola Naumov who was able to show by direct observation of microcytotoxicity chambers that hepatocytes expressing core antigens were preferentially destroyed by $T$ cells, while those only expressing hepatitis B surface antigen tended to be spared. ${ }^{30}$

The advent of successful $\alpha$-interferon treatment of hepatitis $B$ focused attention on the power of the cytokines, and this has become an increasingly important research area in the Unit in recent years. Graeme Alexander who has played such an important part in directing this work refers in detail to this current research programme in the next article.

\section{IMMUNOPATHOGENESIS OF DRUG INDUCED HEPATITIS}

The notion that idiosyncratic drug induced liver injury might be the result of similar mechanisms to that postulated for virus induced disease followed easily from the Unit's earlier work, and became testable when Adrian Eddleston and Mike Davis shared the Senior Lecturer's small office in the Unit in the mid 70s. The bare bones of the hypothesis was that the immune response, if one existed, was directed at antigenic determinants on existing cell surface molecules modified by drug metabolites, and the principle behind the test we devised was to give animals the drug in the hope that their liver cells would show the altered determinants and that these would in turn bind antibodies to these antigens in the patient's blood. Halothane hepatitis, although rare, seemed to be a good example to start with, and Diego Vergani was soon able to show that antibodies in the serum of patients who had developed unexplained severe hepatitis after halothane anaesthesia could bind to the surface of hepatocytes from rabbits anaesthetised with halothane. ${ }^{31}$ The detective work that then followed, which linked this immunological reaction to the metabolism of the drug, and the application of this general approach to the study of the immunopathology of alcoholic liver 
Figure 3: An anti-Dane antibody response is found in hepatitis $B$ virus $(H B V)$ infection in the first week of one of those with chronic $H B V$ infection. From Alberti et al. ${ }^{25}$ most patients with acute the illness (left), but in only

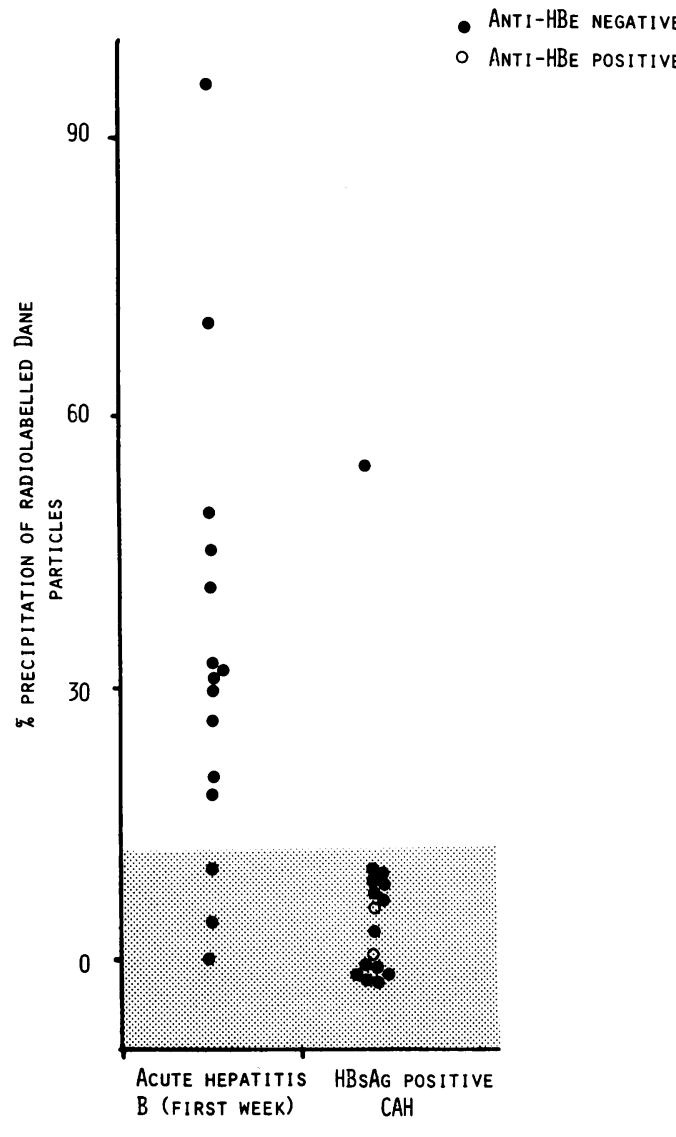

disease, is well covered in later articles in this series.

\section{IMMUNOGENETICS}

The tissue typing group at King's are perhaps unique among their fellow histocompatability locus experts in that they are part of a Liver Unit and not an offshoot of a Department of Haematology or Immunology. This reflects an early interest of the Unit's immunology section in histocompatability locus and its relation to the

Figure 4: Lymphocyte cytotoxicity to the patient's own liver cells in chronic $H B V$ infection is blocked by monoclonal anti-core (anti$H B c$ ) antibodies but not by anti-HBs, suggesting that core antigen may be the target for immune mediated $T$ cell cytolysis of $H B V$ infected hepatocytes.
BLOCKING EFFECT OF ANTIVIRAL ANTIBODIES

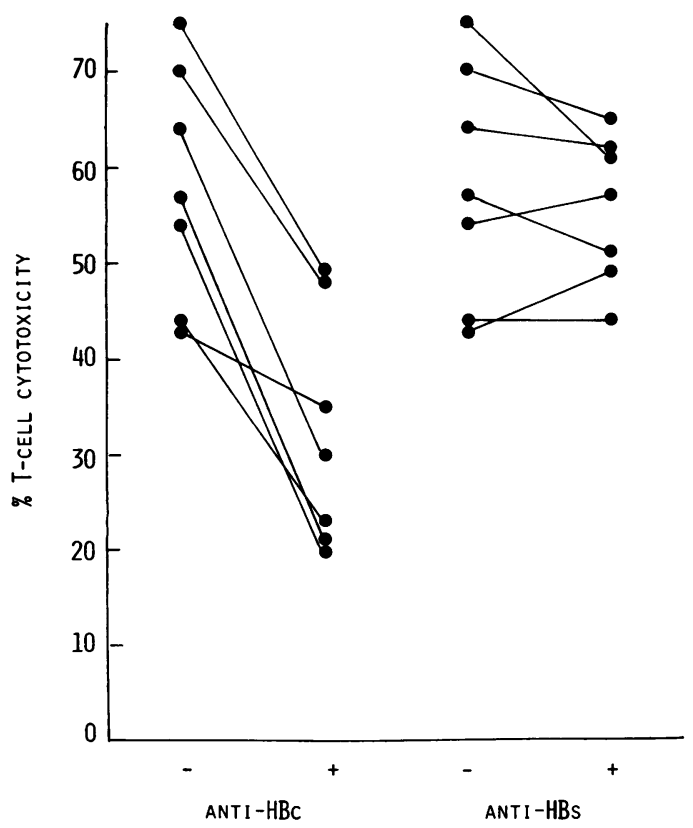

immunogenetics of liver disease. In the early years this work was expertly guided by Professor Richard Batchelor, now at the Royal Postgraduate Medical School, and in 1979 continued interest in this area lead to the appointment of a tissue typist in the new Sheik Zaid laboratory in the Liver Unit. It soon became clear that running a successful tissue typing group single-handed is no easy task, and in 1982, a second appointment was made. Peter Donaldson has been with the Unit ever since and, thanks to the success of joint projects with Alex Mowat in Child Health, which lead to financial support from the Cystic Fibrosis Research Trust, he was joined by Derek Doherty in 1986. The sophistication of the approach to the definition of HLA loci and their antigens has increased dramatically over the last 16 years. In the first publication on histocompatability locus in liver disease form the Unit in 1974, we were able to look at only two loci and a handful of antigens, while today at least six polymorphic loci have been identified coding for over 120 different antigens. The technology of tissue typing has also changed, with molecular techniques, analysing variations at the DNA level, taking over from conventional serological techniques. The most important discoveries in the organisation of the HLA loci during this period were the discovery of the class II genes, at first DR and then DQ and DP, and the mapping of the complement genes coding for the complement components $\mathrm{C} 4 \mathrm{~A}$ and $\mathrm{C} 4 \mathrm{~B}$ between the $\mathrm{B}$ and DR loci.

Autoimmune chronic active hepatitis is, in many respects, a classical organ specific autoimmune disease, with a female preponderance, circulating autoantibodies, both non-organspecific (antinuclear and antismooth muscle) and organ specific (reacting with the asialoglycoprotein receptor), a clinical association with other organ specific autoimmune diseases, and marked steroid responsiveness. Mackay and Morris provided further evidence in support of this classification when they showed that the disease was strongly associated with HLA Al and $B 8,{ }^{32}$ the antigens found in many of the other organ-specific autoimmune diseases. In 1974, Bob Galbraith, a newly arrived clinical research fellow, confirmed these findings in a series of 57 patients with chronic active hepatitis and suggested, for the first time, that the HLA B8 association was confined to the 'autoimmune' form of the disease, with hepatitis B surface antigen positive cases having a different immunogenetic background. ${ }^{33}$ The hypothesis that B8 might be associated with a non-antigen specific increase in immune responsiveness, proposed by Eddleston and Williams, ${ }^{9}$ was supported by a further study from Galbraith, who showed that titres of autoantibodies and antiviral antibodies were higher in B8 positive patients and first degree relatives. ${ }^{34}$ Direct confirmation of a link between $B 8$ and suppressor cell function was obtained by Kayhan Nouri-Aria in $1985 .{ }^{35} \mathrm{~A}$ close association with a newly discovered HLA class II allele, Dw3, was reported by Opelz et al in $1977,{ }^{36}$ and confirmed by Mackay and Tait in $1980,{ }^{37}$ who showed that in autoimmune chronic active hepatitis, as in other autoimmune diseases, B8 and DR3 are inherited together as a haplotype. 


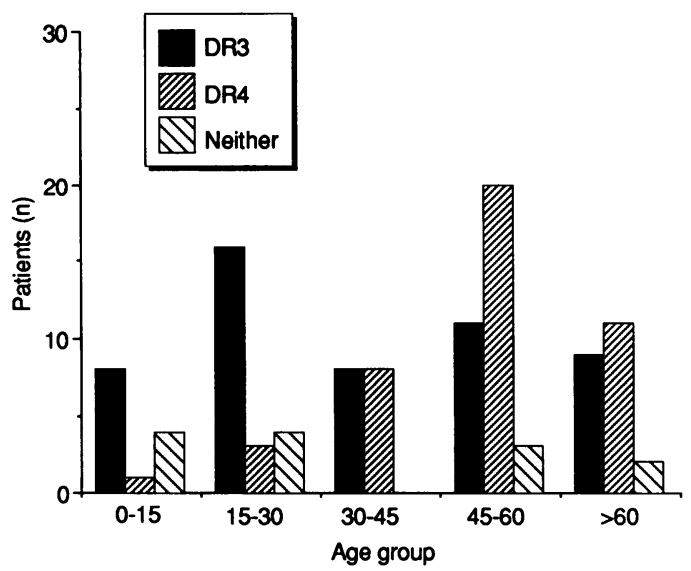

Figure 5: The distribution of the HLA class II DR3 and DR4 genes in patients with autoimmune chronic active hepatitis according to the age of presentation of the disease. There is a bimodal distribution of DR3, which is particularly prominent in the younger patients. DR4 is almost restricted to the older patient group.

Peter Donaldson has recently completed a major review of HLA associations in autoimmune chronic active hepatitis and has found that there are almost certainly two major forms of the disease. The classical B8, DR3 associated type is found in a younger age group, while an older subset, often presenting in women around the menopause, is strongly associated with DR4 (Fig 5). Interestingly, in Japan, where DR3 is very uncommon in the population, DR4 is the main histocompatability locus association with the disease, and most cases occur in older women.

Primary sclerosing cholangitis is another B8, DR3 associated disease. The association with B8 was first described in 1983 by Chapman et al, ${ }^{38}$ and with DR3 in 1982 by Schrumpf et al. ${ }^{39}$ Shepherd et al in 1983, confirmed these findings in 16 patients. ${ }^{40}$ These studies involved relatively small numbers of patients, and a major advantage of the Liver Unit, as a large referral centre, is that substantial series can be assembled. A study of 81 well-characterised patients now in press by Donaldson et al ${ }^{41}$ shows the importance of this approach, for another histocompatability locus association has been revealed in addition to B8, DR3. Excluding the $56 \%$ of patients with DR3, the majority of the remainder had DR2, and these presented at a significantly older age than the DR3 positive group.

The picture of this dual HLA association in primary sclerosing cholangitis is very similar to that in autoimmune chronic active hepatitis, with the associations being in quite separate groups of patients. This is different to some of the other immune mediated diseases with dual HLA associations, like diabetes and coeliac disease, where there is an increased frequency of individuals positive for both associated antigens. In insulin-dependent diabetes mellitus, for example, it has been hypothesised that this is due to the production of a particular HLA class II heterodimer made up of $\mathrm{DQ} \alpha$ and $\mathrm{DQ} \beta$ chains coded for by DQA and DQB alleles linked to DR3 and DR4. Each of the two 6th chromosomes can contribute either both $\alpha$ and $\beta$ chains (cis) or one from each (trans). The situation in chronic active hepatitis and primary sclerosing cholangitis seems to be different, with perhaps only one of the DQ $\alpha$ or $D Q \beta$ chains being particularly important in determining susceptibility in the two different forms of the disease. In either case it is likely that the special class II molecule created is permissive for the disease because it efficiently presents peptide components of the relevant antigen to helper $\mathrm{T}$ cells, or does not properly activate inhibitory immune mechanisms. In a broader context, it is likely that this HLA association is only part of a permissive gene pool which interacts with environmental factors such as viruses, drugs or chemicals to trigger the disease process.

In Bob Galbraith's original report in 1974, he also examined some patients with primary biliary cirrhosis and found no association with any histocompatability locus antigens. Although sporadic reports of associations with DR3 and DR2 have since been published, three large studies have confirmed no significant HLA link with these antigens. Two studies have recently suggested a small but significant association with DRw8, and this has been confirmed in an analysis of a large group of 111 patients with primary biliary cirrhosis from the Liver Unit. However, although significantly increased in frequency compared to a control group, DRw8 was present in only $13 \%$ of the patients, leaving $87 \%$ with no apparent HLA susceptibility marker.

Molecular biology has provided marvellous tools for clinical scientists, and its impact on immunogenetics has been formidable. The advent of more sophisticated techniques, now available in the unit, for the detection of DQ and DP alleles, using sequence-specific oligonucleotide probing of DNA from the relevant genes, amplified from peripheral blood leucocyte DNA by the polymerase chain reaction, provide stringent tests for disease susceptibility markers and are beginning to open up insights into the molecular immunological basis of immune mediated diseases. In autoimmune liver disease, as with other organ-specific autoimmune conditions, speculation in the Unit already extends to the role of novel class II $\alpha \beta$ heterodimers in the presentation of peptides from liver autoantigens and possibly crucial aminoacid substitutions in the antigen presenting groove of the class II molecule.

\section{CONTROLLED CLINICAL TRIALS}

From the earliest days, the Unit has been an important provider of controlled clinical trials, which have allowed more rational decisions about therapy in liver disease to be made. One of the first clinical trials undertaken in the Unit concerned the relative efficacy of prednisolone $v$ azathioprine in autoimmune chronic active hepatitis, and was published as early as $1973 .{ }^{42} \mathrm{~A}$ number of trials in primary biliary cirrhosis then followed and are described in a later article, as are the $\alpha$-interferon trials in viral hepatitis.

Further trials in autoimmune chronic active hepatitis were stimulated by the arrival of an Irish Research Fellow, John Hegarty, who became interested in the treatment of this condition after an initial investigation of prednisolone 
withdrawal had shown a very high relapse rate, even in those patients who were apparently in complete remission. ${ }^{43}$ Hegarty pointed out that there was no evidence as to whether azathioprine, frequently used in combination with prednisolone in autoimmune chronic active hepatitis, ${ }^{44}$ was contributing significantly to the control of disease activity. Working from the hypothesis that the effect of azarthioprine might be most apparent in those patients already controlled on combination treatment, Hegarty together with Tony Stellon showed that azathioprine withdrawal in autoimmune chronic active hepatitis was followed by a significantly increased rate of relapse over the next few months. ${ }^{45}$ Stellon then went on to show that patients successfully established on a combination of azathioprine and prednisolone could be sustained on $2 \mathrm{mg} / \mathrm{kg}$ of azathioprine alone,${ }^{46}$ although the stability of this control was not always as secure as on the combination. These studies have provided a sound factual base for the design of individual therapeutic regimes for patients with autoimmune chronic active hepatitis, in which the power and potential toxicity of steroids, can be married to the relatively safer, slower acting, but less powerful effects of azathioprine.

Ideally, the immunological basis of the effects of these drugs should be well known so that a logical approach to therapy could be adopted. Unfortunately, although some modes of action have been described, ${ }^{16}$ and others postulated, ${ }^{47}$ this still represents a black hole which remains to be illuminated.

1 Eddleston ALWF, Blendis LM, Osborn SB, Williams R. Significance of increased 'splenic uptake' on liver scintiscanning. Gut 1969; 10: 711-4.

2 Soborg M. Bendixen G. Human lymphocyte migration as a parameter of hypersensitivity. Acta Med Scand 1967; 181: 247-56.

3 Eddleston ALWF, Williams R, Calne RY. Cellular immune response during rejection of a liver transplant in man. Nature 1969; 222: 674 .

4 Meyer zum Buschenfelde KH, Kossling FK, Miescher PA. Experimental chronic active hepatitis in rabbits following immunisation with human liver proteins. Clin Exp Immuno 1972; 11: 92-108.

5 Miller J, Smith MGM, Mitchell CG, Reed WD, Eddleston ALWF, Williams R. Cell-mediated immunity to a liverspecific antigen in patients with active chronic hepatitis and primary biliary cirrhosis. Lancet 1972 ; ii: $296-7$.

6 McFarlane IG, Wojcicka B M, Zucker GM, Eddleston ALWF, Williams R. Purification and characterisation of human liver-specific membrane lipoprotein (LSP). Clin Exp Immunol 1977; 27: 381-6.

7 Thomson AD, Cochrane AMG, McFarlane IG, Eddleston ALWF, Williams R. Lymphocyte cytotoxicity to isolated ALWF, Williams R. Lymphocyte cytotoxicity to isolated 721-2.

8 Cochrane AMG, Moussouros A, Thomson AD, Eddleston ALWF, Williams R. Antibody-dependent cell-mediated (K-cell) cytotoxicity against isolated hepatocytes in chronic active hepatitis. Lancet 1976; i: 441-4.

9 Eddleston ALWF, Williams R. Inadequate antibody response to HBAg or suppressor T-cell defect in development of active chronic hepatitis. Lancet 1974; ii: 1543-5.

10 Jensen DM, McFarlane IG, Portmann BS, Eddleston ALWF, Williams R. Detection of antibodies directed against a liverspecific membrane lipoprotein in patients with acute and specific membrane lipoprotein in patients with acute
chronic active hepatitis. $N$ Engl f Med 1978; 299: 1-7.

11 McFarlane IG, McFarlane BM, Major GN, et al. Identification of the hepatic asialogylycoprotein receptor (hepatic lectin) as component of liver-specific membrane lipoprotein (LSP). a component of liver-specific memb

12 McFarlane BM, McSorley CG, Vergani D, et al. Serum autoantibodies reacting with the hepatic asialoglycoprotein receptor protein (hepatic lectin) in acute and chronic liver disorders. F Hepatol 1986; 3: 196-205.

13 Wen L, Peakman M, Lobo-Yeo A, et al. T-cell-directed hepatocyte damage in autoimmune chronic active hepatitis. Lancet 1990; 336: 1527-30.

14 Eddleston ALWF, McFarlane IG, Mitchell CG, Reed WD, Williams $R$. Cell-mediated immune response in primary
biliary cirrhosis to a protein fraction from human bile. $B M \mathcal{F}$ 1973; iv: $274-5$.
15 McFarlane IG, Wojcicka BM, Tsantoulas DC, Portmann B Eddleston ALWF, Williams R. Leucocyte migration inhibition in response to biliary antigens in primary biliary cirrhosis, sclerosing cholangitis and other chronic liver disease. Gastroenterology 1979; 76: 1333-5.

16 Nouri-Aria KT, Hegarty JE, Alexander GJM, Eddleston ALWF, Williams R. The effects of corticosteroids on suppressor cell activity in 'autoimmune' and viral chronic active hepatitis. $N$ Engl f Med 1982; 307: 1301-3.

17 Vento S, Hegarty JE, Bottazzo G, Macchia E, Williams R, Eddleston AL. Antigen specific suppressor cell function in autoimm

18 O'Brien CJ, Vento S, Donaldson PT, et al. Cell-mediated immunity and suppressor-T-cell defects to liver-derived antigens in families of patients with autoimmune chronic active hepatitis. Lancet 1986; i: 350-3.

19 Vento S, O'Brien CJ, McFarlane IG, Williams R, Eddleston AL. T-cell inducers of suppressor lymphocytes control liverdirected autoreactivity. Lancet 1987; i: 886-8.

20 Dudley FJ, Fox RA, Sherlock S. Cellular immunity and hepatitis-associated, Australia antigen liver disease. Lancet 1972; i: 723-6.

21 Reed WD, Zuckerman AJ, Bowes A, et al. Detection of hepatitis-B antigen by radioimmunoassay in chronic liver disease and hepatocellular carcinoma in Great Britain. Lancet 1973; ii: $690-4$.

22 Reed WD, Eddleston ALWF, Cullens H, Williams R. Infusion of hepatitis B antibody in antigen positive active chronic hepatitis. Lancet 1973; ii: 1347-51.

23 Lee WM, Reed WD, Mitchell CG, et al. Cellular and humoral immunity to hepatitis-B surface antigen in active chronic hepatitis. $B M \mathcal{F}$ 1975; i: 705-8.

24 Swanson NR, Reed WD, Yarred LJ, Shilkin KB, Joske RA. Autoantibodies to isolated human hepatocyte plasma membranes in chronic active hepatitis. II. Specificity of antibodies. Hepatology 1990; 11:613-21.

25 Alberti A, Diana S, Eddleston ALWF, Scullard GH, Williams $R$. Detection of a new antibody system reacting with dane particles in hepatitis B virus infection. BMF 1978; ii: 1056-8.

26 Alberti A, Gerlich WH, Heermann K-H, Pontisso P. Nature and display of hepatitis $B$ virus envelope proteins and the humoral immune response. Semin Immunopathol 1990; 12: 5-23.

27 Mieli-Vergani G, Vergani D, Jenkins PJ. Lymphocyte cytotoxicity to autologous hepatocytes in HBsAg-negative

28 Mieli-Vergani G, Vergani D, Portmann B, et al. Lymphocyte cytotoxicity to autologous hepatocytes in $\mathrm{HBsAg}$-positive chronic liver disease. Gut 1982; 23; 1029-36.

29 Mondelli M, Mieli-Vergani G, Alberti A, et al. Speciticity of T lymphocyte cytotoxicity to autologous hepatocytes in chronic hepatitis $B$ virus infection: evidence that $T$ cells are directed against HBV core antigen expressed on hepatocytes. F Immunol 1982; 129: 2773-8.

30 Naumov NV, Mondelli M, Alexander GJ, Tedder RS, Eddleston AL, Williams R. Relationship between expression of hepatitis $B$ virus antigens in isolated hepatocytes and autologous lymphocyte cytotoxicity in patients with chronic hepatitis B virus infection. Hepatology 1984; 4: 63-8.

31 Vergani D, Mieli-Vergani G, Alberti A, et al. Demonstration of a circulating antibody reacting with the surface membrane of halothane-altered hepatocytes in patients with fulminant hepatitis following halothane anaesthesia. $N$ Engl f Med 1980; 303: 66-9.

32 MacKay IR, Morris PJ. Association of autoimmune chronic hepatitis with HL-A1,8. Lancet 1972; ii: 793-5.

33 Galbraith RM, Eddleston ALWF, Smith MGM, et al. Histocompatibility antigens in active chronic hepatitis and primary biliary cirrhosis. $B M \mathcal{F} 1974$; iii: $604-6$

34 Galbraith RM, Eddleston ALWF, Williams R, et al. Enhanced antibody responses in active chronic hepatitis: relation to HLA-B8 and HLA-B12 and porto-systemic shunting. Lancet 1976; i: 930-3.

35 Nouri-Aria KT, Donaldson PT, Hegarty JE, Eddleston AL, Williams R. HLA A1-B8-DR3 and suppressor cell function in first-degree relatives of patients with autoimmune chronic active hepatitis. $\mathcal{F}$ Hepatol 1985; 1 : 235-41.

36 Opelz G, Vogten AJM, Summerskill WHJ, Schalm SW, Teraski PI. HLA determinants in chronic active liver disease: possible relation of HLA-Dw3 to prognosis. Tissue Antigens 1977; 9: 36-40.

37 MacKay IR, Tait BD. HLA associations with autoimmune type chronic active hepatitis: identification of B8-DRw3 haplotype by family studies. Gastroenterology 1980;79:95-8.

38 Chapman RW, Varghese Z, Gaul R, Patel G, Kokinon N, Sherlock S. Association of primary sclerosing cholangitis with HLA-B8. Gut 1983; 24: 38-41.

39 Schrumpf E, Fausa O, Forre O, Dobloug JH, Ritland S, Thorsby E. HLA antigens and immunoregulatory $T$ cells in Thorsby E. HLA antigens and immunoregulatory T cells in ulcerative colitis associated with hepa

40 Shepherd HA, Selby WS, Chapman RWG, et al. Ulcerative colitis and persistent liver dysfunction. Qf Med 1983; 208: 503-13.

41 Donaldson PT, Farrant JM, Wilkinson ML, Hayllar K, Portmann BC, Williams R. Dual association of HLA DR2 and DR3 with primary sclerosing cholangitis. Hepatology 1991 (in press)

42 Murray-Lyon IA, Stern RB, Williams R. Controlled trial of prednisone and azathioprine in active chronic hepatitis. Lancet 1973; i: 735-7. 
43 Hegarty JE, Nouri-Aria KT, Portmann B, Eddleston AL, Williams $R$. Relapse following treatment withdrawal in patients with autoimmune chronic active hepatitis. Hepatology 1983; 3: 685-9.

44 Soloway RD, Summerskill WHJ, Baggentstoss AH, et al. Clinical, biochemical and histological remission of severe chronic active liver disease: a controlled study of treatments and early prognosis. Gastroenterology 1972; 63: 820-33.

45 Stellon AJ, Hegarty JE, Portmann B, Williams R. Randomised controlled trial of azathioprine withdrawal in autoimmune chronic active hepatitis, Lancet 1985; i 668-70.

46 Stellon AJ, Keating JJ, Johnson PJ, McFarlane IG, Williams R. Maintenance of remission in autoimmune chronic active hepatitis with azathioprine after corticosteroid withdrawal. Hepatology 1988; 8: 781-4

47 McFarlane IG, Eddleston ALWF. Chronic active hepatitis. In: Targan S, Shanahan F, eds. Immunology and immunopathology of the liver and gastrointestinal tract, Los Angeles: Igaku-Shoin, 1989: 281-304. 